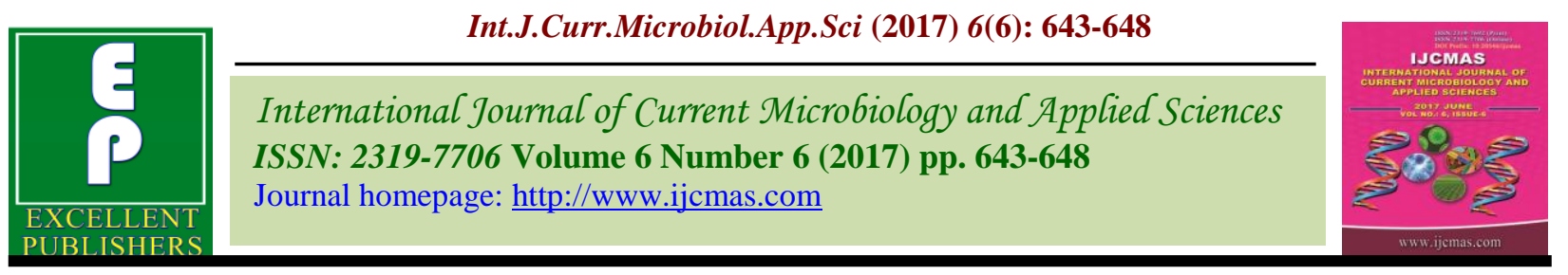

Original Research Article

https://doi.org/10.20546/ijcmas.2017.606.076

\title{
Green gram (Vigna radiata L.) Productivity and Grain Quality enrichment through Zinc Fertilization
}

\author{
Partha Deb Roy $^{1,2}$, K. Lakshman ${ }^{3 *}$, R.P. Narwal ${ }^{1}$, R.S. Malik ${ }^{1}$ and Sushanta Saha ${ }^{4}$ \\ ${ }^{1}$ Department of Soil Science, CCS Haryana Agricultural University, Hisar, \\ Haryana-125 004, India \\ ${ }^{2}$ ICAR-NBSS \& LUP, Regional Centre-Jorhat, India \\ ${ }^{3}$ Jute research Station, Katihar-854105, Bihar Agricultural University, Sabour, India \\ ${ }^{4}$ Bidhan Chandra Krishi Vishwavidalaya, Mohanpur - 741 252, Nadia, West Bengal, India \\ *Corresponding author
}

\section{A B S T R A C T}

Keywords

Green Gram,

Zinc,

Foliar,

Genotype, Crude Protein.

Article Info

Accepted:

xx May 2017

Available Online:

xx June 2017
A pot experiment was conducted at CCSHAU, Hisar during the year 201011 to study the effect of zinc fertilization on green gram productivity and grain quality. Zinc was applied @ $0,5.5 \mathrm{~kg}$ as basal and $0.1 \% \mathrm{Zn}$ as foliar application. Seven green gram genotypes viz. Asha, Basanti, Satya, MH421, MH 318, and MH-565 were selected for the study. Pods per plant, seeds per pod and seed weight significantly increased with the application of $\mathrm{Zn}$ which ultimately increased the yield of seed and straw of all the green gram genotypes. However, application of $5.5 \mathrm{~kg} \mathrm{Zn}$ ha-1 increased the yield of straw by $30.8 \%$ which was better as compare to foliar treatment. The maximum $\mathrm{Zn}$ concentration in straw and seed (about 5 and 3 folds over control) was achieved when foliar spray was made. Soil application of $\mathrm{Zn}$ increased the seed crude protein content by $9.96 \%$ over control.

\section{Introduction}

In and post green revolution era research on agriculture was mainly targeted to increase food production. Increased use of high analysis chemical fertilizers, high yielding crop varieties and increase in cropping intensity done the job well, but at the same time led to enhanced micronutrients deficiency in soil. As much as 48, 12, 5, 4, 33, 13 and $41 \%$ soils in India have been found affected with deficiencies of zinc, iron, manganese, copper, boron, molybdenum and sulphur, respectively (Singh, 2009). These deficiencies are causing not only hidden hunger but also leading to entire failure of crops and lower content of trace elements in plant parts. In Haryana, $28.27 \%$ areas in zinc are fall under low to moderately low in category (AICRP, 2011). Along with the previous reasons alkaline reaction, low organic matter, high calcium carbonate and coarse texture nature of soils added to create such limiting condition (Malik et al., 2008). 
Legumes are the important source of protein for human nutrition. Green gram, originated in Indian sub-continent (Condolle, 1886), is one of the most widely cultivated pulse crops in the country and is grown on about $3.44 \mathrm{~m}$ ha with the annual production of $1.4 \mathrm{mt}$ along with the productivity of $406.98 \mathrm{~kg} / \mathrm{ha}$ (Anonymous, 2011). Green gram (Vigna radiata $\mathrm{L}$.) when grown under zinc deficient soils suffers from yield loss. The extent of yield loss varies with the magnitude of deficiency of these micronutrients in soils and variety used (Bansal et al., 1991). Fertilization is the key point of nutrient management in agronomic approaches to enhance crop yield and quality. Therefore the present investigation was planned to study the influence of zinc application on green gram productivity and seed quality.

\section{Materials and Methods}

Soil sample of surface layer $(0-15 \mathrm{~cm})$ was collected from village Balsamand (Hisar) district. The soil was air dried ground and passed through $2 \mathrm{~mm}$ sieve. The basal soil sample was again mixed and stored in cloth bags for further analysis of relevant physicochemical characteristics of soil. The basal soil sample had Textural class- Sand, $\mathrm{pH}-8.72$, E.C.-0.52 dSm ${ }^{-1}, \quad$ O.C.-0.12\%, $\mathrm{CaCO}_{3}-$ Nil,CEC - 3.7 and DTPA-extractable Zn, $0.52 \mathrm{mg} \mathrm{kg}^{-1}$ soil.

Four kg thoroughly mixed soil from district Hisar was filled in each plastic pot placed in completely randomized way in the screen house.

Basal application of recommended doses of $\mathrm{N}, \mathrm{P}$ and $\mathrm{K}$ were applied. Three rates of $\mathrm{Zn} \mathrm{[0,}$ 5.5 and foliar $(0.1 \% \mathrm{Zn})]$ through $\mathrm{ZnSO} 4$, $7 \mathrm{H} 2 \mathrm{O}$ were applied in respective pots. Ten seeds of each of the seven genotypes of green gram (Asha, Basanti, Satya, MH 421, MH 318, MH 565 and Muskan) were sown.
Thinning was done after one week and four uniform plants per pot were allowed to grow up to maturity. In the case of foliar application, two sprays of $0.1 \% \mathrm{Zn}$, at pre- flowering and pod initiation stage were applied. At maturity, grain and straw yield was recorded and samples of straw and seed were ground in a stainless steel grinder and digested with di- acid mixture $\left(\mathrm{HNO}_{3}\right.$ and $\mathrm{HClO} 4,4: 1)$. The $\mathrm{Zn}$ concentration in plant digests was determined by DTPA method. Crude protein in seed was calculated by multiplying total seed $\mathrm{N}$ with 6.25. The data was statistically analyzed using Microsoft Excel and OP stat computer software.

\section{Results and Discussion}

\section{Branches per plant}

The result shown in table 1 revealed that soil application of zinc increased the number of branches per plant in all green gram genotypes significantly over control while foliar application was not able to do so. Similar results were obtained by Ahmadi (2010) in rapeseed and Khorgamy and Farnia (2009) in Chickpea. Higher number of branches per plant with zinc application may be due to more vegetative growth in the zinc treated plant in deficient soil condition. Foliar application alone was not able to increase branching because it was applied at late growth stages when branching was almost completed.

\section{Pods per plant}

From the data in table 1 it can be highlighted that $\mathrm{Zn}$ treatments either soil or foliar significantly increased the number of pods per plant over control. Among the zinc application methods, soil application @ 5.5 $\mathrm{kg} \mathrm{Zn} \mathrm{ha}{ }^{-1}$ application was found to increase the pod number from 6.17 per plant to 7.05 over control. Highest number of pods per 
plant was obtained in Muskan genotype (7.92) while lowest number of pods per plant was observed in MH 318 (5.28). Higher number of pods per plant with zinc application could possibly be explained by the fact that zinc application increased the realisation of flower into pods (Ghildayal et al., 1978). Similar type of results was obtained by Ahmadi et al., (2010) on rapeseed. As compared to foliar application (6.75), basal application of recommended zinc fertilizer increased pods per plant (7.05). This might be due to more dry matter accumulated in initial growth stage in the plant that received basal application and subsequently utilized it for pod development (Ghildayal et al., 1978).

\section{Seeds per pod}

The data in table 1 revealed that zinc treatments increased seeds per pod in all the green gram genotypes significantly over control. The highest number of seeds per pod (6.90) was however recorded under basal application of zinc@5.5 kg ha ${ }^{-1}$. Among genotypes Basanti and Satya gave the highest number of seeds (6.77) per pod while in case of $\mathrm{MH} 565$ and $\mathrm{MH} 421$ least number of seeds per pod (5.56) was recorded. Seeds per pod were also increased with zinc application over control (Table 1) which might be due to the role of zinc in seed setting (Marschner, 1995).

\section{Seed weight}

Hundred seed weight of green gram genotypes was found to increase significantly over control with the application of zinc either by basal or foliar. The results in table 1 depicted that basal application of $5.5 \mathrm{~kg} \mathrm{Zn}$ ha- 1 recorded with 4.17 gram per 100 seed weight. While foliar application of $\mathrm{Zn}$ recorded the minimum weight of 4.10 gram among all the treatments. Significant differences were also observed among all the seven genotypes of green gram. Muskan was in the top of the list with 4.17 gram; while MH 565 placed at the bottom with 4.01 gram per 100 seed weight. No significant interaction was found between treatment and genotype. Test weight is one of the most important yield components in pulse crop. Similar results were obtained by Khorgamy and Farnia (2009) in chickpea for zinc application.

Fig.1 Effect of zinc application methods on its concentration in straw and seed

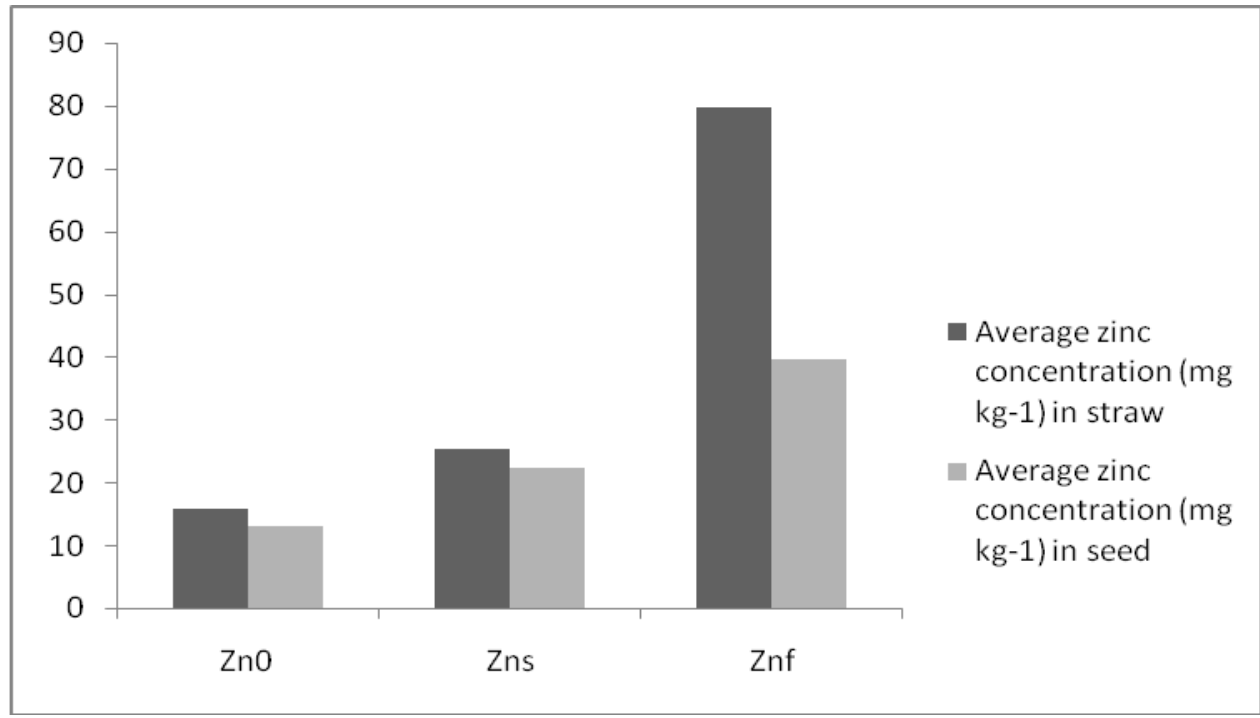


Table.1 Effect of zinc application methods on yield attributes of green gram genotypes

\begin{tabular}{|c|c|c|c|c|c|c|c|c|c|c|c|c|}
\hline \multirow[t]{2}{*}{ Genotype } & \multicolumn{3}{|c|}{ Branches/plant } & \multicolumn{3}{|c|}{ Pods/plant } & \multicolumn{3}{|c|}{ Seeds/pod } & \multicolumn{3}{|c|}{100 seed weight } \\
\hline & $\mathrm{Zn}_{0}$ & $\mathrm{Zn}_{\mathrm{s}}$ & $\mathrm{Zn}_{\mathrm{f}}$ & $\mathrm{Zn}_{0}$ & $\mathrm{Zn}_{\mathrm{s}}$ & $\mathrm{Zn}_{\mathrm{f}}$ & $\mathrm{Zn}_{0}$ & $\mathrm{Zn}_{\mathrm{s}}$ & $\mathrm{Zn}_{\mathrm{f}}$ & $\mathrm{Zn}_{0}$ & $\mathrm{Zn}_{\mathrm{s}}$ & $\mathrm{Zn}_{\mathrm{f}}$ \\
\hline Asha & 3.16 & 4.00 & 3.33 & 5.83 & 6.67 & 7.58 & 5.00 & 7.33 & 5.33 & 3.92 & 4.15 & 4.00 \\
\hline Basanti & 3.67 & 4.25 & 4.00 & 5.83 & 6.67 & 6.33 & 5.67 & 7.33 & 7.33 & 4.07 & 4.10 & 4.08 \\
\hline Satya & 3.67 & 4.00 & 3.75 & 6.67 & 7.67 & 7.67 & 5.67 & 7.67 & 7.00 & 4.10 & 4.15 & 4.10 \\
\hline MH 421 & 3.33 & 3.67 & 3.67 & 5.00 & 5.83 & 5.00 & 5.00 & 6.00 & 5.67 & 3.99 & 4.21 & 4.10 \\
\hline MH 318 & 3.33 & 3.67 & 3.33 & 5.67 & 6.67 & 5.83 & 5.33 & 6.00 & 5.67 & 4.04 & 4.25 & 4.19 \\
\hline MH 565 & 3.67 & 4.00 & 3.83 & 6.67 & 7.50 & 6.92 & 5.00 & 6.00 & 5.67 & 3.88 & 4.09 & 4.07 \\
\hline Muskan & 3.33 & 4.08 & 3.67 & 7.50 & 8.33 & 7.92 & 5.00 & 8.00 & 5.33 & 4.08 & 4.26 & 4.17 \\
\hline Mean & 3.45 & 3.95 & 3.65 & 6.17 & 7.05 & 6.75 & 5.24 & 6.90 & 6.00 & 4.01 & 4.17 & 4.10 \\
\hline $\mathrm{CD}$ at $5 \%$ & \multicolumn{3}{|c|}{ Treatment $=0.44$} & \multicolumn{3}{|c|}{ Treatment $=0.29$} & \multicolumn{3}{|c|}{ Treatment $=0.71$} & \multicolumn{3}{|c|}{ Treatment $=0.07$} \\
\hline
\end{tabular}

Table.2 Effect of zinc application methods on yield and on crude protein content (\%) of green gram genotypes

\begin{tabular}{|c|c|c|c|c|c|c|c|c|c|}
\hline \multirow[t]{2}{*}{ Genotype } & \multicolumn{3}{|c|}{ Straw yield $\left(\mathbf{g}_{\text {pot }}{ }^{-1}\right)$} & \multicolumn{3}{|c|}{ Seed yield( g pot $\left.^{-1}\right)$} & \multicolumn{3}{|c|}{$\begin{array}{l}\text { Seed crude protein content } \\
(\%)\end{array}$} \\
\hline & $\mathrm{Zn}_{0}$ & $\mathrm{Zn}_{\mathrm{s}}$ & $\mathrm{Zn}_{\mathrm{f}}$ & $\mathrm{Zn}_{0}$ & $\mathrm{Zn}_{\mathrm{s}}$ & $\mathrm{Zn}_{\mathrm{f}}$ & $\mathrm{Zn}_{0}$ & $\mathrm{Zn}_{\mathrm{s}}$ & $\mathrm{Zn}_{\mathrm{f}}$ \\
\hline Asha & 33.7 & 42.0 & 40.5 & 4.96 & 6.32 & 5.99 & 24.3 & 26.5 & 25.8 \\
\hline Basanti & 38.0 & 58.2 & 54.5 & 5.55 & 7.79 & 8.22 & 24.3 & 27.2 & 25.0 \\
\hline Satya & 45.6 & 60.5 & 54.2 & 6.36 & 9.88 & 9.02 & 23.0 & 25.0 & 25.8 \\
\hline $\mathrm{MH} 421$ & 29.0 & 39.0 & 36.2 & 4.16 & 5.04 & 5.54 & 24.3 & 25.1 & 26.4 \\
\hline MH 318 & 36.5 & 47.2 & 42.2 & 5.21 & 6.87 & 6.96 & 24.6 & 26.5 & 25.7 \\
\hline MH 565 & 39.4 & 50.2 & 45.1 & 5.60 & 6.98 & 7.14 & 21.1 & 25.0 & 25.7 \\
\hline Muskan & 46.0 & 53.1 & 51.2 & 6.70 & 7.65 & 7.35 & 19.9 & 22.4 & 21.7 \\
\hline Mean & 38.3 & 50.1 & 46.2 & 5.51 & 7.22 & 7.17 & 23.1 & 25.4 & 25.2 \\
\hline $\mathrm{CD}$ at $5 \%$ & \multicolumn{3}{|c|}{ Treatment $=3.8$} & \multicolumn{3}{|c|}{ Treatment $=0.56$} & \multicolumn{3}{|c|}{ Treatment $=1.3$} \\
\hline
\end{tabular}


Overcoming the limitations of plant nutrient through application of appropriate fertilizers, increases assimilate production and photosynthesis efficiency during the seed development stage (Yilmaz et al., 1997; Calhor, 2006).

\section{Yield}

The result shown in table 2 revealed that straw yield of all green gram genotypes increased significantly over control with zinc application. However, basal application of 5.5 $\mathrm{kg} \mathrm{Zn} \mathrm{ha}{ }^{-1}$ increased the straw yield to the tune of $30.8 \%$ over control. Only foliar application of zinc increased straw yield to $20.6 \%$ over control. Straw yield was also significantly differed among different genotype. Highest straw yield (53.43 $\left.\mathrm{g} \mathrm{pot}^{-1}\right)$ was recorded in Satya genotype while $\mathrm{MH}$ 421 gave average lowest yield of $34.73 \mathrm{~g} \mathrm{pot}^{-1}$ was lowest among rest of the genotypes. The favourable effect of various methods of zinc application on straw yield of green gram might be due to its direct influence on auxin production which in turn enhanced the elongation processes of plant development as reported by Singh and Badhoria (1984). The increase in straw yield $(20.6 \%$ over control) was low in the treatments that received only foliar application. Foliar application at late growth stage attributed to less vigorous vegetative growth as compared to basal application of recommended dose. Secondly, the amount of nutrient applied through foliar may not be sufficient to meet the requirement of plants.

Seed yield of all the green gram genotypes increased significantly over control at zinc application. As evident from table 2 basal application of zinc gave the seed yield of 7.17 gram pot $^{-1}$. Application of zinc increased seed yield of green gram genotypes significantly over control (Table 2) because zinc application under their stress environment provided better conditions for the pod formation and subsequent increase in number of seeds per pod.

\section{Zinc content}

Application of zinc fertilizer increased zinc concentration in straw significantly over control. The result shown in graph 1 revealed that maximum zinc concentration in straw was achieved when foliar application of $\mathrm{Zn}$ was made. Zinc concentration in straw was found low irrespective of all genotypes, where zinc was applied @ $5.5 \mathrm{~kg} \mathrm{Zn} \mathrm{ha}{ }^{-1}$. Similar trend we found in seed zinc concentration also.

\section{Seed crude protein content}

The increments in content of critical micronutrients can materially increase the vigour, disease resistance, grain yield as well as quality of the crop grown on soil deficient in the treatment nutrient. From the data in table 2, it can be said that $\mathrm{Zn}$ application significantly increased the crude protein content in seed of green gram over control. No significant difference was found between soil and foliar application with respect to crude protein content enhancement. Highest crude protein content in seed $(25.5 \%)$ was found in Basanti genotype. While in Muskan the lowest content of protein $(21.3 \%)$ was recorded. Application of micronutrient fertilizers particularly zinc provides a double benefit i.e. increase in grain yield and improving the nutritional quality of the harvested produce. For green gram, the viability, vigour and protein contents may be the prime quality characteristics that determines market price. The possible explanation for increasing crude protein content is that zinc is involved in protein metabolism through several enzyme systems (Singh and Badhoria, 1984; Zhang et al., 2009). 
From the above results it can be conclude that among various methods of $\mathrm{Zn}$ fertilization, basal application of recommended dose was effective in increasing yield and crude protein of all the green gram genotypes. While foliar application of zinc is was more effective to increase zinc loading in straw or grain and thus may be a potential tool to fight against Zn malnutrition in developing countries.

\section{References}

Ahmadi, M. 2010. Effect of zinc and nitrogen fertilizer rates on yield and yield components of oilseed rape (Brassica napus L.). World Appl. Sci. J., 10(3): 298303.

AICRP Micronutrient Scheme. 2011. Department of Soil Science, CCS HAU, Hisar, Haryana.

Anonymous. 2011. http://www.naipsrl.org/ IKisan/agricultural-allied-information/cropinformation/green-gram. aspx.

Bansal, R.L., Nayyar, V.K. and Takkar, P.N. 1991. Field screening of wheat cultivars for manganese efficiency. Field Crops Res., 29: 107-112.

Calhor, M. 2006. Effect of nitrogen and zinc on yield of durum wheat in khoramabad region. Agricultural Research Institute, Lorestan, Iran.

Condolle, A.P.de. 1886. Origin of cultivated plants. $2^{\text {nd }}$ edn. Pp. 468. Reprinted 1959. Hafner publishing co., New York. p. 465.

Ghildiyal, M.C., Tomar, O.P.S. and Sirohi, G.S. 1978. Response of cowpea genotypes to zinc in relation to photosynthesis, nodulation and dry matter distribution. Plant Soil, 49: 505-516.

\section{How to cite this article:}

Partha Deb Roy, K. Lakshman, R.P. Narwal, R.S. Malik and Sushanta Saha. 2017. Green Gram (Vigna radiata L.) Productivity and Grain Quality Enrichment through Zinc Fertilization. Int.J.Curr.Microbiol.App.Sci. 6(6): 643-648. doi: https://doi.org/10.20546/ijcmas.2017.606.076
Khorgamy, A. and Farnia, A. 2009. Effect of phosphorus and zinc fertilisation on yield and yield components of chick pea cultivars. African Crop Sci. Conference Proceedings, Vol. 9. pp. $205-208$.

Malik, R.S., Narwal, R.P., Ramkala, Singh, M.V. and Dahia, R.R. 2008. Secondary and micronutrients status and response to crops in soils of Haryana. Indian $J$. Fertilisers, 4(2): 53-58.

Marschner, H. 1993. Zinc uptake from soils. In: Robson AD (Ed) Zinc in Soils and Plants. Kluwer, Dordrecht, the Netherlands, pp. 59-77.

Marschner, H. 1995. Mineral Nutrition of Plants. 2 Ed. Academic Press, Boston.

Singh, M.V. 2009. Micronutrient nutritional problems in soils of India and improvement for human and animal health. Indian J. Fertilizers, 5(4): 11-16, $19-26 \& 56$.

Singh, B. and Badhoria, B.S. 1984. Response of green gram to potassium and zinc application. J. Agri. Sci., 102: 253 - 255.

Yilmaz, A., Ekiz, H., Torun, B., Gultekin, I., Karanlik, S., Bagci, S.A. and Cakmak, I. 1997. Effect of different zinc application methods on grain yield and zinc concentration in wheat grown on zincdeficient calcareous soils in Central Anatolia. J. Plant Nutri., 20: 461-471.

Zhang, J., Wang, M.Y. and Wu, L.H. 2009. Can foliar iron-containing solutions be a potential strategy to enrich iron concentration of rice grains (Oryza sativa L.)? Acta Agriculturae Scandinavica Section B -Soil and Plant Sci., 59: 389 394. 